\title{
Effect of the Natural Cat and Dog Liquid Additives on 3\% Salt Fed Rats
}

\author{
Elif Rabia Sanli ${ }^{1}$, MusaYavuz ${ }^{*}$, Zafer Özyıldız², Veli Uygur ${ }^{3}$ \\ ${ }^{1}$ Department of Animal Science, Faculty of Agriculture, Isparta University of Applied Sciences Isparta, Turkey. \\ ${ }^{2}$ Department of Pathology, Veterinary Faculty, Mehmet Akif Ersoy University, Burdur, Turkey \\ ${ }^{3}$ Soil Science and Plant Nutrition, Faculty of Agriculture, Igdir University, Igdir, Turkey \\ *Corresponding author. Email: musayavuz@isparta.edu.tr
}

\begin{abstract}
Salt poisoning could be important for the pets' life. High salt and low water consumptions can be effective in the formation of salt poisoning. Low levels of salt poisoning increase blood pressure which reduces the quality of life. Plant-origin cat and dog liquid additives are previously used and improve water consumption of rats. In this study, 36 wistar albino rats were randomly divided into 4 groups (regular diet with water (RDW), 3\% salt containing diet with water (SW) or cat (SCat) or dog (SDog) liquid additives added to their water). Animals were fed ad libitum for two weeks. At day 0 and day 14, blood samples were collected from the rats. At Day 14 , the rats were individually placed in metabolic cages and urine and fecal samples were also taken. The rats were subjected to necropsy and kidney tissue was removed. Sodium (Na) concentration of urine samples were $36 \%$ SCat and $45 \%$ SDog higher than those measured in the SW groups. Na concentration of the feces was higher in SW groups (27\% or 47\%) than those in the SCat and SDog groups, respectively. According to the kidney tissue microscopic findings, the health conditions of the SCat and SDog groups, supplemented with the additive were improved. Especially, SDog product reduced the negative effects of elevated salt intake on rats.
\end{abstract}

Keywords: Rat, salt, poisoning, liquid additives

\section{INTRODUCTION}

With the developing technology, human beings and pets are in contact with thousands of substances that can have toxic effects in their environment [1]. One of them is salt. Salt is frequently used in our daily life as a flavoring additive and nutritional requirement of most foods for all living things. The sodium chloride is of the most frequently used and readily available salts supplying electrolytic balance of the body. Excessive use of each substance causes toxic effects, like salt intake. Low levels of salt poisoning cause increased blood pressure, reducing quality of life.

There are various medicinal plants used in traditional medicine through preventing and treating diseases. The effects of liquid additives obtained from the mixture of a variety of medicinal plants [2] were investigated in rats fed with $3 \%$ salt containing feed.

\section{MATERIALS AND METHODS}

\subsection{Liquid Additives Products}

The heyLove Cat Detox and heyLove Dog Detox products were kindly provided by ATY Grup Yem San. ve Tic. A.Ş., Istanbul, Turkey [2]. The products are known to be produced with liquid additives prepared from the extracts of 11 plants, which are arranged according to the needs of cats and dogs, respectively, to neutralize free radicals accumulated in the body and to strengthen immunity $[3,4]$.

\subsection{Animals and groups}

Thirty-six male Wistar albino rats at fifty-four weeks age (428.36 $\pm 12.34 \mathrm{~g})$ were housed (Ethics Committee Protocols No: 93773921-239) at the Laboratory of Animal Experiments, Faculty of Veterinary Medicine, Mehmet Akif Ersoy University, Burdur, Turkey. The rats were individually housed in the cages. Feed and water with liquid additives were given as ad-libitum. The feed of rats was prepared (soybean, oats, anchovy flour, and commercial layer chicken vit-min) at the Department of Animal Science Laboratory Isparta University of Applied Sciences, Faculty of Agriculture. Each cage was randomly divided into four groups: a) The main feed mixture and commercial water were given to the RDW group, b) the salt added feed and commercial water were given to the SW group, c) the salt added feed and $20 \%$ cat detox were given to the SCat group, and d) the salt added feed and $\% 20$ to the SDog group dog detox was 
given. The detox products were diluted with commercial water.

\subsection{Blood sampling}

Blood was drawn for serum chemistry on day 1 and day 14 [5]. Urea, creatinine, sodium, chlorine, calcium, phosphorus and potassium analyzes were performed at the the Labotaroty of Veterinary Faculty of Mehmet Akif Ersoy University, Burdur, Turkey.

\subsection{Urine and fecal sampling}

In the experiment, at the end of the $14^{\text {th }}$ day, the rats were placed in individual metabolic cages (three rats each from the RDW, SW, SCat and SDog groups) and urine and fecal samples were collected for 24-hour periods. The urine samples were stored at $-20^{\circ} \mathrm{C}$ after the quantities were determined, and then sent by cold chain, to Düzen Norwest Laboratory, Çankaya, Ankara, Turkey for analysis. After the fecal samples were weighed and recorded in their wet state, they were first subjected to drying for analysis and their dry quantities were recorded. Dry matter and crude ash levels were determined after grinding feces. Later, sodium, calcium and potassium analysis of fecal samples was determined at Isparta University of Applied Sciences, Agricultural Faculty, Soil Science and Plant Nutrition Laboratory, Isparta, Turkey, [6] and phosphorus contents of fecal digests were spectrophotometrically determined by the blue dye method [7].

\subsection{Necropsy and pathological examination}

The anesthesia-euthanasia was performed by cervical dislocation method. Euthanized animals were immediately subjected to necropsy to check the anatomical location of the abdominal, thoracic and pelvic cavities and internal organs. The kidney tissues examination was performed by strictly following the Mohan's [8] criteria for studying of renal toxic injury.

\subsection{Statistical Analysis}

Data were analyzed by using a commercially available statistical software package [9]. The means of the groups were compared through Duncan's multiple range tests after all data were subjected to Analysis of Variance.

\section{RESULTS AND DISCUSSION}

\subsection{Blood Parameters}

The urea, creatinine, total protein, albumin, AST, ALT, ALP, GGT, sodium, chloride, calcium, phosphorus and potassium levels of blood serum are shown in Table 1 .

Table 1. Blood serum parameters of the rats.

\begin{tabular}{|l|c|c|c|c|c|}
\hline \multicolumn{1}{|c|}{ Blood chemistry } & RDW & SW & Scat & SDog & Average \\
\hline Urea $(\mathrm{mg} / \mathrm{dL})$ & $30.17 \pm 3.87$ & $33.20 \pm 9.87$ & $31.00 \pm 4.47$ & $30.90 \pm 3.03$ & $31.46 \pm 6.04$ \\
\hline Creatinine $(\mathrm{mg} / \mathrm{dL})$ & $0.61 \pm 0.02$ & $0.64 \pm 0.02$ & $0.63 \pm 0.04$ & $0.62 \pm 0.03$ & $0.62 \pm 0.03$ \\
\hline Total Protein $(\mathrm{g} / \mathrm{dL})$ & $7.20 \pm 0.15$ & $7.07 \pm 0.28$ & $7.23 \pm 0.68$ & $7.01 \pm 0.30$ & $7.12 \pm 0.41$ \\
\hline Albumin $(\mathrm{g} / \mathrm{dL})$ & $2.84 \pm 0.12$ & $2.97 \pm 0.27$ & $3.36 \pm 0.47$ & $3.39 \pm 0.16$ & $3.17 \pm 0.37$ \\
\hline AST $(\mathrm{U} / \mathrm{L})$ & $107.28 \pm 18.85$ & $93.07 \pm 35.08$ & $105.56 \pm 11.93$ & $105.48 \pm 14.15$ & $105.16 \pm 22.59$ \\
\hline
\end{tabular}

The differences in the creatinine, total protein, albumin, AST, ALT, GGT values among treatment groups were not statistically significant, whereas the urea and ALP levels were statistically different between the treatment groups. According to the studies conducted, the serum urea level varies depending on the nutritional value of the feed. Despite the fact that it was aimed to meet the nutrition needs of the rats, the serum urea level was determined to be higher than those reported in the literature $[2,10]$. Serum ALP level can be high for many reasons and needs to be evaluated by considering in other parameters.

\subsection{Urine and Feces Parameters}

Some physico-biochemical properties of the urine samples are given in Table 2. In the physical examination of the urine, it was observed that the color of the urine changed from light yellow to dark brown according to the amount of water they consumed. In addition, as water consumption increased, the urine specific gravity of rats increased. The urine volume, $\mathrm{pH}$ and specific gravity of rats were not significantly different between the treatment groups. The rat's urine volume, $\mathrm{pH}$ and specific gravity values were significantly influenced from the treatments which were in agreement with the other studies [11-17]. 
Table 2. The volume, physical and biochemical characteristics of urine

\begin{tabular}{|c|c|c|c|c|c|}
\hline $\begin{array}{c}\text { Urine } \\
\text { characteristics }\end{array}$ & RDW & SW & SCat & SDog & Average \\
\hline $\begin{array}{l}\text { Output volume } \\
\text { (mL/day) }\end{array}$ & $6.55 \pm 3.92$ & $14.39 \pm 5.21$ & $14.86 \pm 10.43$ & $14.86 \pm 10.43$ & $13.31 \pm 8.72$ \\
\hline Density $(\mathrm{g} / \mathrm{L})$ & $1014.17 \pm 5.85$ & $1019.44 \pm 5.83$ & $1014.50 \pm 3.69$ & $1017.00 \pm 7.53$ & $1016.43 \pm 6.01$ \\
\hline $\mathrm{pH}$ & $7.17 \pm 0.41$ & $6.72 \pm 0.97$ & $7.20 \pm 0.42$ & $6.95 \pm 0.93$ & $7.00 \pm 0.75$ \\
\hline Protein $(\mathrm{g} / \mathrm{L})$ & $0.92 \pm 0.49$ & $1.00 \pm 0.50$ & $0.75 \pm 0.46$ & $0.63 \pm 0.53$ & $0.80 \pm 0.49$ \\
\hline Glucose (mmol/L) & $3.00 \pm 0.00$ & $3.00 \pm 0.00$ & $3.00 \pm 0.00$ & $3.00 \pm 0.00$ & $3.00 \pm 0.00$ \\
\hline Ketone $(\mathrm{mmol} / \mathrm{L})$ & $0.67 \pm 0.41$ & $1.16 \pm 0.51$ & $0.79 \pm 0.49$ & $1.00 \pm 0.54$ & $0.90 \pm 0.50$ \\
\hline Bilirubin (mmol/L) & $17.00 \pm 0.00$ & $17.00 \pm 0.00$ & $17.00 \pm 0.00$ & $17.00 \pm 0.00$ & $17.00 \pm 0.00$ \\
\hline $\begin{array}{l}\text { Urobilinogen } \\
(\mu \mathrm{mol} / \mathrm{L})\end{array}$ & $17.00 \pm 0.00$ & $17.00 \pm 0.00$ & $17.00 \pm 0.00$ & $17.00 \pm 0.00$ & $17.00 \pm 0.00$ \\
\hline Blood (Ery/ $\mu \mathrm{L})$ & $216.67 \pm 81.65$ & $238.89 \pm 33.33$ & $200.00 \pm 52.70$ & $190.00 \pm 96.61$ & $210.00 \pm 69.45$ \\
\hline $\begin{array}{l}\text { Leukocyte Esterase } \\
(\text { Leu/ } \mu \mathrm{L})\end{array}$ & $25.00 \pm 0.00$ & $25.00 \pm 0.00$ & $25.00 \pm 0.00$ & $25.00 \pm 0.00$ & $25.00 \pm 0.00$ \\
\hline Erythrocyte & $12.80 \pm 4.97$ & $13.75 \pm 7.32$ & $14.50 \pm 6.54$ & $9.80 \pm 5.69$ & $12.64 \pm 6.31$ \\
\hline Leukocyte & $1.83 \pm 0.98$ & $2.63 \pm 1.69$ & $2.00 \pm 1.49$ & $2.40 \pm 1.35$ & $2.24 \pm 1.39$ \\
\hline $\begin{array}{l}\text { Squamous } \\
\text { epithelium }\end{array}$ & $1.60 \pm 0.89$ & $4.00 \pm 3.04$ & $4.60 \pm 3.13$ & $3.11 \pm 3.06$ & $3.58 \pm 2.93$ \\
\hline Atp crystal & $13.33 \pm 2.89$ & $11.00 \pm 6.90$ & $9.33 \pm 4.08$ & $13.67 \pm 7.09$ & $11.28 \pm 5.38$ \\
\hline
\end{tabular}

The results of urine biochemical analysis of the rats are shown in Table 2. According to the results, all groups, including the RDW group, contain undesirable substances in the urine. However, the urine parameters of rats were similar in all groups. Protein, glucose, ketone, bilirubin, urobilinogen, blood, leukocyte esterase, erythrocyte, leukocyte, squamous epithelium and Atp crystals should not be present in the urine. However, kidney disorders were observed in rats according to urine biochemical results depending on the protein level of the feed given to rats [18].

Mineral concentrations of urine fed with salt-rich diet are given in Table 3. It was found that the difference between the groups in urinary sodium, chlorine and potassium levels were statistically significant. Urine mineral levels were similar to the literature values $[13,16,19]$.

Table 3. Urine mineral analysis of rats

\begin{tabular}{|c|c|c|c|c|c|}
\hline Chemical parameter & RDW & SW & SCat & SDog & Average \\
\hline Sodium (mg/dL) & $171.33 \pm 64.83 B$ & $70.78 \pm 42.26 \mathrm{~A}$ & $102.90 \pm 40.54 \mathrm{~A}$ & $96.50 \pm 48.39 \mathrm{~A}$ & $104.54 \pm 56.59$ \\
\hline Chloride (mg/dL) & $24.50 \pm 9.04 \mathrm{~A}$ & $119.37 \pm 63.51 \mathrm{~B}$ & $88.60 \pm 28.48 B$ & $125.56 \pm 68.17 \mathrm{~B}$ & $99.00 \pm 59.42$ \\
\hline Calcium (mg/dL) & $8.02 \pm 4.47$ & $11.50 \pm 8.13$ & $10.24 \pm 5.50$ & $11.37 \pm 10.50$ & $10.51 \pm 7.57$ \\
\hline Phosphorus (mg/dL) & $78.97 \pm 26.74$ & $110.60 \pm 48.76$ & $93.59 \pm 52.67$ & $102.09 \pm 55.21$ & $97.89 \pm 47.34$ \\
\hline Potassium (mg/dL) & $59.03 \pm 27.47 \mathrm{AB}$ & $36.57 \pm 13.45 \mathrm{~A}$ & $52.66 \pm 20.55 A B$ & $66.96 \pm 24.23 B$ & $53.70 \pm 23.57$ \\
\hline
\end{tabular}

Physical examination of the feces revealed that there were consistent softness, color, odor and shape in the normal ranges. The fecal amount was highly dependent on the individuals. This in fact is a function of food consumption behavior of the individuals. The average daily wet feces weight of the rats for the experimental period was $4.25 \pm 2.16 \mathrm{~g}$. The analysis results for the fecal dry matter and fecal raw ash percentages of the rats and the amounts of minerals fecal excreta are shown in Table 4 . The fecal ash contents increased with excessive 
salt supplementation. Sodium and chloride concentrations in excretion of the feces were accordingly increased with salt supplement.

Table 4. Fecal dry matter, raw ash and minerals of rats

\begin{tabular}{|l|l|l|l|l|l|}
\hline $\begin{array}{l}\text { Chemical } \\
\text { parameters }\end{array}$ & RDW & SW & SCat & SDog & Average \\
\hline Dry matter (\%) & $57.69 \pm 26.68$ & $57.89 \pm 17.32$ & $61.90 \pm 14.87$ & $61.59 \pm 16.99$ & $60.01 \pm 17.74$ \\
\hline Ash (\%) & $4.57 \pm 1.08^{A}$ & $6.40 \pm 1.39^{\mathrm{B}}$ & $6.42 \pm 1.71^{\mathrm{B}}$ & $7.15 \pm 1.62 \mathrm{~B}$ & $6.28 \pm 1.69$ \\
\hline $\begin{array}{l}\text { Sodium } \\
\text { (mg/dL) }\end{array}$ & $316.38 \pm 151.28^{\mathrm{A}}$ & $638.70 \pm 357.95^{\mathrm{B}}$ & $467.18 \pm 249.44 \mathrm{~A}^{\mathrm{B}}$ & $339.12 \pm 104.07^{\mathrm{A}}$ & $452.07 \pm 265.55$ \\
\hline $\begin{array}{l}\text { Chloride } \\
\text { (mg/dL) }\end{array}$ & $1.93 \pm 1.02^{\mathrm{A}}$ & $4.24 \pm 2.76^{\mathrm{A}}$ & $6.07 \pm 4.05 \mathrm{~A}^{\mathrm{B}}$ & $10.06 \pm 6.42 \mathrm{~B}$ & $5.87 \pm 4.91$ \\
\hline $\begin{array}{l}\text { Calcium } \\
\text { (mg/dL) }\end{array}$ & $299.76 \pm 167.43$ & $298.74 \pm 168.08$ & $419.07 \pm 125.12$ & $293.30 \pm 148.62$ & $333.17 \pm 152.89$ \\
\hline $\begin{array}{l}\text { Phosphorus } \\
\text { (mg/dL) }\end{array}$ & $0.94 \pm 0.17$ & $0.87 \pm 0.07$ & $1.36 \pm 0.90$ & $0.83 \pm 0.11$ & $1.02 \pm 0.54$ \\
\hline $\begin{array}{l}\text { Potassium } \\
\text { (mg/dL) }\end{array}$ & $1038.04 \pm 411.51$ & $1083.32 \pm 303.94$ & $829.72 \pm 220.33$ & $1064.22 \pm 428.80$ & $1000.91 \pm 349.29$ \\
\hline
\end{tabular}

A, B Letters on the same line give the difference between groups $(\mathrm{P}<0.05)$.

The SW group had the highest value of the treatment groups. The usage of SCat and SDog additives elevated chloride removal from the rats.

\subsection{Pathological findings}

After autopsy, kidney tissues of rats were taken and tissue surfaces and sections were examined microscopically. Among the experimental groups, it was determined that a significant difference was only found in proteinaceous mass of the kidney tissues of rats. Other criteria showed insignificant differences (Table 5).

Table 5. Pathological findings results of kidney tissues of rats

\begin{tabular}{|l|c|c|c|c|}
\hline & RDW & SW & SCat & SDog \\
\hline $\mathrm{N}$ & 6 & 6 & 6 & $13.20^{\mathrm{A}}$ \\
\hline Proteinous mass & $5.75^{\mathrm{B}}$ & $15.17^{\mathrm{A}}$ & $14.08^{\mathrm{A}}$ & 7.50 \\
\hline Bow. Gap Expansion & 8.83 & 15.50 & 14.17 & 10.80 \\
\hline Tubular degeneration & 7.25 & 15.83 & 13.92 & 10.60 \\
\hline Tubulus necrosis & 1015 & 15.67 & 10.75 & 11.90 \\
\hline Fibrotice change & 11.17 & 9.33 & 15.58 & \\
\hline
\end{tabular}

A, B Letters on the same line give the difference between groups $(\mathrm{P}<0.05)$.

The kidneys of the SW group had moderately pale and swollen areas. Other groups were quite normal without any abnormalities. Microscopic examination of rat kidney tissue showed a reduction in degenerative changes in the proximal convolute and distal tubular epithelium, in the tubular lumen in proteinaceous masses, and in the medullary and arterial perivascular edema compared to the SW group. Degenerative changes in the SDog group were significantly reduced compared to the SCat group (Figure 1). 


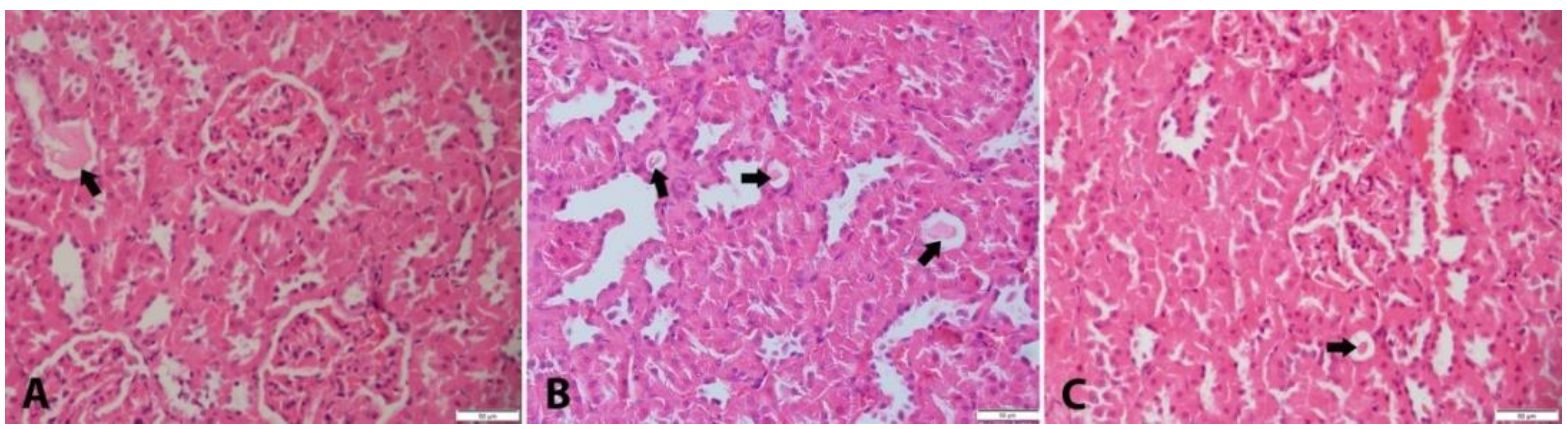

Figure 1. Images of kidney tissues of rats A: SW, B: SCat and C: SDog groups (Arrows indicate proteinaceous masses), H\&E, barr $50 \mu$.

\section{CONCLUSION}

The consumption of 3\% salt-enriched diet did not affect the serum, urine and fecal biochemical levels of rats. There was a change in the amount of excreted urine and feces of rats depending on the salt intake level. However, urinary sodium excretion of rats was higher for SCat and SDog groups than the SW group. The fecal sodium excretion of rats was found to be higher for SCat and SDog groups than the SW group. Furthermore, according to the kidney tissue microscopic findings, it was determined that the conditions of the groups consuming SCat and SDog products improved. Especially SDog product reduced deleterious effects of saline on rats.

\section{ACKNOWLEDGMENTS}

We would like to thank to people who helped (Vet. Zeki EROL, PhD. Student Vet. Aysegül AVSAR and Phd. Student Fatih ŞAHINER for taking care of the animals. Prof. Dr. Ozlem OZMEN's advise during research and Prof. Dr. Metin SEZER's help for statistical analyses) in this research. This research was part of the master thesis supported by the ATY Grup Yem San. ve Tic. A.Ş., Istanbul, Turkey.

\section{REFERENCES}

[1] Anonymus, Toxic chemicals in building materials, An overview for health care organizations. https://s3.amazonaws.com/healthy-materialslab/resources/toxic-chemicals-in-buildingmaterials.pdf

[2] Y. Musa, S. E. Rabia, Investigation of the natural cat and dog detox products on rats. Feb-Fresenius Environmental Bulletın 2018; 2985.

[3] Natural

$$
\text { cat }
$$

detox, http://www.heyloveanimal.com/Cat-DetoxNatural.html. (E. Tarihi, 19.04.2019).

[4] Natural $\operatorname{dog}$ detox, http://www.heyloveanimal.com/Dog-DetoxNatural.html. (E. Tarihi, 19.04.2019).
[5] Anonymus: Stresten etkilenen organlar ve etkileri. https://sagligabiradim.com/stresten-en-coketkilenen-organlar/. (E. Tarihi: 01.03.2019).

[6] B. Kacar, A. İnal, Bitki Analizleri. Nobel Yayın No. 1241, Ankara, 2008.

[7] J. Murphy, J. P. Riley, A modified single solution method for the determination of phosphate in natural water. Analytica Chimica Acta. 27 (1962) 31-36.

[8] I. K. Mohan, M. Khan, J. C. Shobha, M. U. R. Naidu, A. Prayag, P. Kuppusamy, V. K. Kutala, Protection against cisplatin-induced nephrotoxicity by Spirulina in rats, Cancer Chemother. Pharmacol. 58 (2006) 802-808. DOI: $10.1007 / \mathrm{s} 00280-006-0231-8$.

[9] SPSS; Versiyon 25. 2018. www.spss.com (Son E. Tarihi: 30.06 .2019 ).

[10] S. Mehrabi, H. Checknezhad, A. Mehrabi, A. Vaziri, Effects of the hydrophilic extract of Juniperus excelsa on renal function in male Wistar rats. J. Renal Inj. Prev. 8(1) (2019) 34-37. DOI: 10.15171 jrip.2019.07.

[11] T. Afsar, S. Razak, A. Almajwal, D. Al-Disi, Doxorubicin-induced alterations in kidney functioning, oxidative stress, DNA damage, and renal tissue morphology, Improvement by Acacia hydaspica tannin-rich ethyl acetate fraction. Saudi J. Biol. Sci. 27(9) (2020) 2251-2260. DOI: https://doi.org/10.1016/j.sjbs.2020.07.011.

[12] D. P Cladis, S. Li, L. Reddivari, A. Cox, M. G Ferruzzi, C. M Weaver, A 90 day oral toxicity study of blueberry polyphenols in ovariectomized Sprague-Dawley rats. Food Chem. Toxicol. 2020 ;
111254. $139 \quad$ (2020)
111254. DOI: 10.1016/j.fct.2020.111254.

[13] A. El-Ghouizi, N. El-Menyiy, S. I. Falcão, M. Vilas-Boas, B. Lyoussi, Chemical composition, antioxidant activity, and diuretic effect of Moroccan fresh bee pollen in rats. Vet. World. 13(7) (2020) 1251-1261. DOI: 
www.doi.org/10.14202/vetworld.2020.125112612

[14] M. J. Lee, Y. H. Chung, H. Y. Choi, H. G. Cha, Evaluation of subchronic repeated administration toxicity of ammonium nitrate in rats. Toxicol. Res. 36(2) (2020) 115-122. DOI: 10.1007/s43188-01900022-4.

[15] Y. Narita, K. Fukumoto, M. Fukunaga, Y. Kondo, Y. Ishitsuka, H. Jono, T. Irie, H. Saito, D. Kadowaki, S. Hirata, Comparative study of constipation exacerbation by potassium binders using a Loperamide-1nduced constipation model. Int. J. Mol. Sci. 21(7) (2020) 2491. DOI: $10.3390 /$ ijms 21072491.

[16] Z. Wang, Y. Bai, J. Wang, J. Wang, The preventive and therapeutic effects of $\alpha$-lipoic acid on ethylene glycol-induced calcium oxalate deposition in rats. Int. Urol. Nephrol. 2020; 1-8. DOI: 10.1007/s11255-020-02423-z.

[17] X.-L. Zhu, T. Zhang, Z.-Q. Xu, X.-C. Ma, Z.-J. Wang, C.-W. Zou, J.-X. Li, H.-Y. Jing, High saltinduced weakness of anti-oxidative function of natriuretic peptide receptor-C and podocyte damage in the kidneys of Dahl rats. Chinese Med. J. 133(10) (2020) 11821191. DOI: $10.1097 / C M 9.0000000000000752$.

[18] Dikmen, S., M. Petek, M. Oğan, E. Onbaşılar, Laboratuvar Hayvanları Yetiştirme ve Sağlığı. Anadolu Üniversitesi Yayını 2441 (2011).

[19] S. El-Guendouz, S. Zizi, Y. Elamine, B. Lyoussi, Preliminary screening of the possible protective effect of Moroccan propolis against chromiuminduced nephrotoxicity in animal model. Vet. World. 13(7) (2020) 1327-1333. DOI: $10.14202 /$ vetworld.2020.1327-1333. 